\title{
First record of Procyrnea sp. (Nematoda: Habronematidae) in Buteogallus schistaceus (Sundevall) (Accipitriformes: Accipitridae) in Brazilian Amazon
}

\author{
Primeiro registro de Procyrnea sp. (Nematoda: Habronematidae) \\ em Buteogallus schistaceus (Sundevall) (Accipitriformes: Accipitridae) \\ na Amazônia Brasileira
}

\begin{abstract}
Tiago Paixão Mangas ${ }^{1}$; Karoline Petrini Pinheiro da $\mathrm{Cruz}^{2}$ (D); Ana Sílvia Sardinha Ribeiro² (D); Raul Henrique da Silva Pinheiro ${ }^{3}$ (D); Raimundo Nonato Moraes Benigno ${ }^{1,2}$ (D); Elane Guerreiro Giese ${ }^{1,2 \star}$ (D); Washington Luiz Assunção Pereira ${ }^{1,2}$ (D)
${ }^{1}$ Programa de Pós-graduação em Saúde e Produção Animal na Amazônia, Instituto da Saúde e Produção Animal, Universidade Federal Rural da Amazônia - UFRA, Belém, PA, Brasil
${ }^{2}$ Instituto da Saúde e Produção Animal, Universidade Federal Rural da Amazônia - UFRA, Belém, PA, Brasi
3Programa de Pós-graduação em Sociedade, Natureza e Desenvolvimento, Instituto de Ciências e Tecnologia das Águas, Universidade Federal do Oeste do Pará - UFOPA, Santarém, PA, Brasil
\end{abstract}

\begin{abstract}
How to cite: Mangas TP, Cruz KPP, Ribeiro ASS, Pinheiro RHS, Benigno RNM, Giese EG, et al. First record of Procyrnea sp. (Nematoda: Habronematidae) in Buteogallus schistaceus (Sundevall) (Accipitriformes: Accipitridae) in Brazilian Amazon. Braz J Vet Parasitol 2020; 29(2): e001420. https://doi.org/10.1590/S1984-29612020032
\end{abstract}

\begin{abstract}
Buteogallus schistaceus (Sundevall) is an endemic bird of prey from the Amazon region, with a declining population according to international conservation agencies. The objective of this study was to report the occurrence of a parasitic nematodes in an individual treated at the Ambulatório de Animais Silvestres of Universidade Federal Rural da Amazônia, Belém campus. The animal was captured on campus and showed no resistance to capture. Fluid therapy and deworming were made, later the bird regurgited ten nematodes identified as belonging to the genus Procyrnea Chabaud (1958). Reviewing the scientific literature, it was found that so far there are no records on the helminth fauna of this bird species, which is therefore the first report of a nematode in B. schistaceus.
\end{abstract}

Keywords: Nematode, Slate-colored Hawk, Pará.

\begin{abstract}
Resumo
Buteogallus schistaceus (Sundevall) é uma ave de rapina endêmica da região amazônica, com população em diminuição, segundo órgãos de conservação internacional. Logo, o objetivo deste trabalho foi relatar a ocorrência de nematódeos parasitos em um indivíduo atendido no Ambulatório de Animais Silvestres, da Universidade Federal Rural da Amazônia, campus Belém. $O$ animal foi capturado nas dependências do campus e não apresentou resistência à captura. Foram então instituídos fluidoterapia e vermifugação, após os quais o animal regurgitou dez nematódeos identificados como pertencentes ao gênero Procyrnea Chabaud (1958). Ao revisar a literatura científica, verificou-se que, até o momento, não existem quaisquer registros sobre a helmintofauna dessa espécie de ave, sendo, portanto, o primeiro relato de um nematódeo em $B$. schistaceus.
\end{abstract}

Palavras-chave: Nematódeos, gavião-azul, Pará. 


\section{Introduction}

The Brazilian avifauna comprises over 1900 species among which 91 are birds of prey (Piacentini et al., 2015). This group is essential for population regulation because they are the end of the food chain (Andery et al., 2013). The Slate-colored Hawk Buteogallus schistaceus (Sundevall) is a non-migrant, diurnal neotropical bird of prey endemic to the Amazon rainforest, which occurs from southern Bolivia, through Peru, Ecuador, Colombia, Venezuela, French Guiana and Brazil; in the latter mainly in the states of Amazonas, Pará and Amapá. It is currently declining in its population, despite being classified in conservation status as "least concern" according to BirdLife International (2016). It has a varied diet that includes lizards, snakes and some insects (e.g., orthopteran and moths) (Robinson, 1994).

Procyrnea Chabaud, 1958 contains 60 species described around the world. Of these, 15 have been reported in the Neotropical Region, ten in Brazil (Table 1). They are parasites of the upper digestive system of birds, especially of the ventricle and proventriculus (Arrona-Rivera et al., 2016). They can cause severe inflammation of the parasitized organ mucosa and consequent organic weakness followed by death (Niemuth et al., 2013).

Table 1. Records to the species of the Neotropical Procyrnea Chabaud, 1958 from birds, indicating their hosts and geographical distributions.

\begin{tabular}{|c|c|c|c|}
\hline Species & Hosts & Locality & Reference \\
\hline $\begin{array}{c}\text { Procyrnea anterovulvata Pinto, Vicente \& } \\
\text { Noronha, } 1996\end{array}$ & Chelidoptera tenebrosa brasiliensis Sclater & Brazil & Pinto et al. (1996) \\
\hline $\begin{array}{c}\text { Procyrnea brevicaudata Zhang, Brooks \& } \\
\text { Causey, } 2004\end{array}$ & Crypturellus cinnamomeus (Lesson) & Costa Rica & Zhang et al. (2004) \\
\hline $\begin{array}{l}\text { Procyrnea choique Bagnato, Frixione, } \\
\text { Digiani \& Cremonte, } 2018\end{array}$ & Rhea pennata (d'Orbigny) & Argentina & Bagnato et al. (2018) \\
\hline Procyrnea colaptes (Walton, 1927) & $\begin{array}{l}\text { Celeus lugubris lugubris (Malherbe) } \\
\text { Celeus elegans jumanus (Spix) }\end{array}$ & $\begin{array}{l}\text { Brazil } \\
\text { Brazil }\end{array}$ & $\begin{array}{l}\text { Pinto et al. (1996) } \\
\text { Pinto et al. (1996) }\end{array}$ \\
\hline Procyrnea leptoptera (Rudolphi, 1819) & $\begin{array}{c}\text { Caracara plancus (Miller) } \\
\text { Falco sparverius cearae (Cory) } \\
\text { Geranospiza caerulescens caerulescens (Vieillot) } \\
\text { Harpagus diodon (Temminck) } \\
\text { Heterospizias meridionalis (Latham) } \\
\text { Milvago chimachima chimachima (Vieillot) } \\
\text { Rupornis magnirostris magnirostris (Gmelin) } \\
\text { Rupornis magnirostris nattereri (Sclater \& Salvin) }\end{array}$ & $\begin{array}{l}\text { Brazil } \\
\text { Brazil } \\
\text { Brazil } \\
\text { Brazil } \\
\text { Brazil } \\
\text { Brazil } \\
\text { Brazil } \\
\text { Brazil }\end{array}$ & $\begin{array}{l}\text { Pinto et al. (1994) } \\
\text { Pinto et al. (1994) } \\
\text { Pinto et al. (1994) } \\
\text { Vicente et al. (1995) } \\
\text { Pinto et al. (1994) } \\
\text { Pinto et al. (1994) } \\
\text { Pinto et al. (1994) } \\
\text { Pinto et al. (1994) }\end{array}$ \\
\hline Procyrnea longistriata (Molin, 1859) & Colaptes campestris (Vieillot) ${ }^{f}$ & Brazil & Cram (1927) \\
\hline $\begin{array}{c}\text { Procyrnea mclennanae Zhang, Brooks \& } \\
\text { Causey, } 2004\end{array}$ & Heliomaster constantii (De Lattre) & Costa Rica & Zhang et al. (2004) \\
\hline Procyrnea mansioni (Seurat, 1914) & $\begin{array}{l}\text { Celeus grammicus (Natterer \& Malherbe)g } \\
\text { Rupornis magnirostris (Gmelin) }\end{array}$ & $\begin{array}{l}\text { Brazil } \\
\text { Brazil }\end{array}$ & $\begin{array}{l}\text { Pinto et al. (1994) } \\
\text { Pinto et al. (1994) }\end{array}$ \\
\hline $\begin{array}{c}\text { Procyrnea mawsonae Zhang, Brooks \& } \\
\text { Causey, } 2004\end{array}$ & Rupornis magnirostris (Gmelin) ${ }^{\mathrm{h}}$ & Costa Rica & Zhang et al. (2004) \\
\hline Procyrnea pileata (Walton, 1927) & $\begin{array}{c}\text { Celeus flavescens flavescens (Gmelin) } \\
\text { Celeus lugubris lugubris (Malherbe) } \\
\text { Celeus elegans jumanus (Spix) }^{\mathrm{b}} \\
\text { Campephilus melanoleucos melanoleucos (Gmelin) } \\
\text { Campephilus robustus (Lichtenstein) } \\
\text { Campephilus rubricollis trachelopyrus (Malherbe) } \\
\text { Picumnus cirratus macconnelli Sharpe } \\
\text { Ramphastos tucanus Linnaeus }\end{array}$ & $\begin{array}{l}\text { Brazil } \\
\text { Brazil } \\
\text { Brazil } \\
\text { Brazil } \\
\text { Brazil } \\
\text { Brazil } \\
\text { Brazil } \\
\text { Brazil }\end{array}$ & $\begin{array}{l}\text { Pinto et al. (1996) } \\
\text { Pinto et al. (1996) } \\
\text { Pinto et al. (1996) } \\
\text { Pinto et al. (1996) } \\
\text { Pinto et al. (1996) } \\
\text { Pinto et al. (1996) } \\
\text { Pinto et al. (1996) } \\
\text { Pinto et al. (1996) }\end{array}$ \\
\hline Procyrnea ruschii (Freitas, 1967) & $\begin{array}{c}\text { Colibri serrirostris (Vieillot) } \\
\text { Chlorostilbon lucidus pucherani (Bourcier \& Mulsant)' }\end{array}$ & $\begin{array}{l}\text { Brazil } \\
\text { Brazil }\end{array}$ & $\begin{array}{l}\text { Vicente et al. (1995) } \\
\text { Vicente et al. (1995) }\end{array}$ \\
\hline Procyrnea spinosa (Gendre, 1923) & $\begin{array}{l}\text { Milvago chimango chimango (Vieillot) } \\
\text { Milvago chimango temucoensis Sclater }\end{array}$ & $\begin{array}{l}\text { Chile } \\
\text { Chile }\end{array}$ & $\begin{array}{l}\text { San Martín et al. (2006) } \\
\text { Oyarzún-Ruiz et al. (2016) }\end{array}$ \\
\hline Procyrnea uncinipenis (Molin, 1860) & Rhea americana (Linnaeus) & Brazil & $\begin{array}{c}\text { Cram (1927) } \\
\text { Ederli \& Oliveira (2019) }\end{array}$ \\
\hline Procyrnea unilateralis (Molin, 1860) & $\begin{array}{l}\text { Ramphastos tucanus Linnaeus }{ }^{m} \\
\text { Ramphastos vitellinus Lichtenstein }\end{array}$ & $\begin{array}{l}\text { Brazil } \\
\text { Brazil }\end{array}$ & $\begin{array}{l}\text { Cram (1927) } \\
\text { Cram (1927) }\end{array}$ \\
\hline Procyrnea waltoni (Freitas \& Lent, 1947) & Rhea americana (Linnaeus) & Brazil & Freitas \& Lent (1947) \\
\hline
\end{tabular}

${ }^{a}$ Cited as Celeus flavescens lugubris; ${ }^{b}$ Cited as Celeus jumana jumana; 'Cited as Polyborus plancus; ${ }^{\mathrm{d} C i t e d}$ as Buteo magnirostris magnirostris; ${ }^{\mathrm{e} C i t e d}$ as Buteo

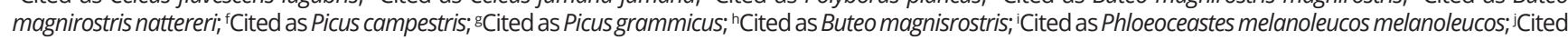
as Phloeoceastes robustus; ${ }^{k}$ Cited as Phloeoceastes rubricollis tracheolopyrus; 'Cited as Chlorostilbon aureoventris pucherani; $\mathrm{m} C$ Cited as Ramphastos erythrorhynchus. 
One hundred and seventy years after its original description, there are still no references to the helminth fauna of $B$. schistaceus in the specialized literature. This fact is of great importance when considering that parasitic action, along with anthropic action, may interfere with its ex situ conservation (Santos et al., 2015). Therefore, the objective of this study was to report the occurrence of Procyrnea sp. in B. schistaceus in the state of Pará, Brazil.

\section{Case report}

A young specimen of Buteogallus schistaceus was received for care at the Ambulatório de Animais Silvestres of Universidade Federal Rural da Amazônia, Belém campus. All applicable institutional, national and international guidelines for the care and use of animals were followed. Scientific Collecting Permits were provided by Comitê de Ética no Uso de Animais (CEUA/ UFRA) (Permit Number 23084.022512/2014-18). The animal was observed by a university official on campus grounds $\left(1^{\circ} 27^{\prime} 12.3^{\prime \prime} \mathrm{S}, 48^{\circ} 26^{\prime} 36.5^{\prime \prime} \mathrm{W}\right)$, who informed the clinic that the bird appeared to be ill. During capture the animal showed no resistance. At clinical examination, the animal was lethargic, with no escape reflex, with moderate dehydration, weighing $453 \mathrm{~g}$. Direct parasitological examination of the feces did not reveal helminth eggs. The therapeutic protocol consisted of subcutaneous fluid therapy $(0.9 \%$ saline solution in a total application of $26 \mathrm{~mL}$ for three days, combined with a single dose of Vitamin A 20,000 IU) and oral deworming (Praziquantel, Pirantel Pamoate and Oxantel Pamoate in combination) in two applications in a 15-day interval. After the first deworming the animal regurgitated ten nematodes that were collected, fixed in AFA (alcohol-formaldehyde) solution and sent to the Animal Helminthology Laboratory for taxonomic identification. Nematode specimens were clarified with 50\% Aman lactophenol and temporarily mounted between slide and coverslip for observation and measurement of morphological characters under light microscope LEICA DM2500 with an imaging capture system. For the taxonomic classification of nematodes, the works of Vicente et al. (1995) and Bagnato et al. (2018) were consulted. Thirty days after admission the animal was returned to the wild.

The nematodes (one male, eight female and one broken specimen) had a thin body, with attenuated extremities and transversely striated cuticle. Mouth with two lips, one ventral and one dorsal, and two lateral pseudolabia with teeth at their anterior border. Esophagus divided into short anterior muscle part and long posterior glandular part. Deirids anterior to the nerve ring. Excretory pore posterior to the nerve ring. Body with two asymetrical lateral alae. Male with unequal and dissimilar spicules. Gubernaculum present. Caudal alae present with longitudinal cuticular thickening. Females with median vulva, of lateral-ventral opening, and pointed tip. These characteristics are compatible with those described for the genus Procyrnea Chabaud, 1958 (Figure 1 and Table 2). Diagnosis at the specific level was not possible due to the collection of a single male with an extremely curled tail, making it impossible to observe the quantity and disposition of the caudal papillae.

Table 2. Morphometric data of Procyrnea sp. (Nematoda: Habronematidae) regurgitated by Buteogallus schistaceus (Sundevall), Belém, Pará State, Brazil. Measurements are given in micrometers unless otherwise stated, with the range followed, in parenthesis, by the mean and standard deviation.

\begin{tabular}{ccc} 
Fatures & \multicolumn{2}{c}{ Procyrnea sp.* } \\
\cline { 2 - 3 } & Male $(\mathbf{n}=\mathbf{1})$ & Female $(\mathbf{n}=\mathbf{8})$ \\
\hline Body lenght, $\mathrm{mm}$ & 9.34 & $9.42-19.40(13.76 \pm 3.39)$ \\
Body width & 120 & $128.00-290.00(239.88 \pm 53.61)$ \\
Left lateral ala lenght & 1.65 & $2.08-5.45(4.33 \pm 1.15)$ \\
Right lateral ala lenght, mm & 3.97 & $1.88-3.05(2.50 \pm 0.39)$ \\
Bucal capsule lenght & 20 & $20.00-25.00(21.14 \pm 2.04)$ \\
Bucal capsule width & 13 & $13.00-20.00(14.57 \pm 2.82)$ \\
Muscular esophagus lenght & 371 & $233.00-528.00(404.50 \pm 87.13)$ \\
Muscular esophagus width & 36 & $33.00-71.00(42.25 \pm 12.96)$ \\
Glandular esophagus lenght, mm & 2.00 & $1.67-2.78(2.16 \pm 0.36)$ \\
Glandular esophagus width & 96 & $43.00-129.00(76.29 \pm 27.18)$ \\
Deiridst & 130 & $50.00-165.00(132.63 \pm 22.74)$ \\
Nerve ringt & 213 & $180.00-250.00(222.38 \pm 36.99)$ \\
Excretory poret & 310 & $242.00-333.00(301.00 \pm 34.53)$ \\
\hline
\end{tabular}

*one broken specimen not included on measurements; ffrom anterior end. 
Table 2. Continued...

\begin{tabular}{ccc}
\hline Fatures & \multicolumn{2}{c}{ Procyrnea sp.* } \\
\cline { 2 - 3 } & Male $(\mathbf{n}=\mathbf{1})$ & Female $(\mathbf{n}=\mathbf{8})$ \\
\hline Tail & 217 & $153.30-243.00(188.54 \pm 30.73)$ \\
Right spicule & 316 & - \\
Left spicule & 880 & - \\
Gubernaculum & 37 & $3.97-6.71(5.67 \pm 0.96)$ \\
Vulva, mm ${ }^{\dagger}$ & - & $28.00-34.00(30.94 \pm 2.48)$ \\
Egg length & - & $14.33-17.00(15.72 \pm 1.12)$ \\
Egg width & - & \\
\hline
\end{tabular}

*one broken specimen not included on measurements; tfrom anterior end.
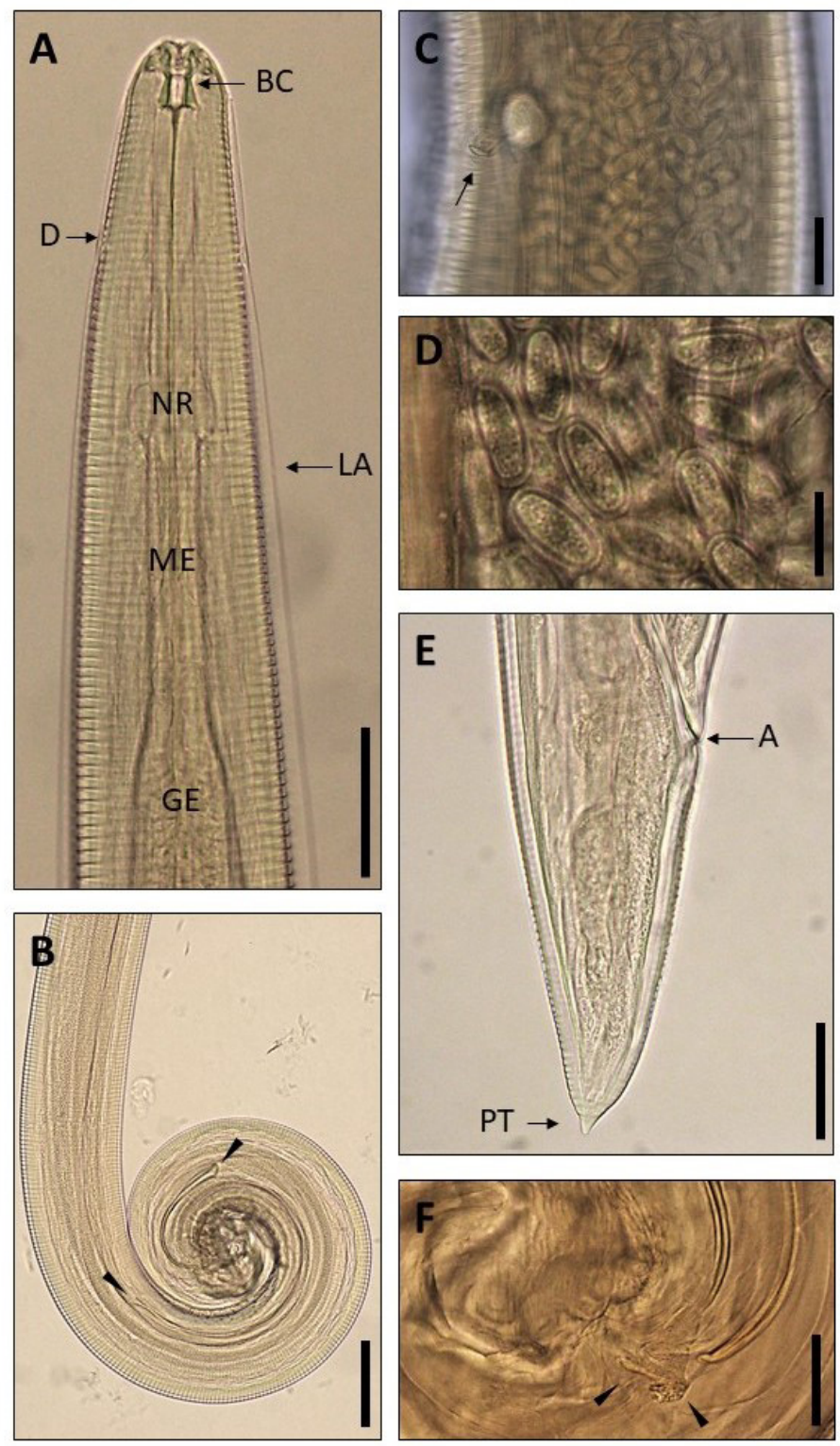

Figure 1. Photomicrographs of Procyrnea sp. (Nematoda: Habronematidae) regurgitated by Buteogallus schistaceus (Sundevall), Belém, Pará State, Brazil. (A) Male anterior end, ventral view. Note the lateral ala on each side of the body. Bar: $100 \mu$ m; (B) Male tail, lateral view. Arrowheads indicate the beginning of spicules. Bar: $200 \mu \mathrm{m}$; (C) Vulva (arrow), lateral view. Bar: $50 \mu$ m; (D) View of the eggs. Bar: $25 \mu \mathrm{m}$; (E) Female tail with, lateral view. Bar: $50 \mu \mathrm{m}$; (F) Detail of the posterior end of the spicules and gubernaculum (arrowheads). Bar: $50 \mu \mathrm{m}$. Abbreviations: $\mathrm{A}=$ anus; $\mathrm{BC}=$ buccal capsule; $\mathrm{D}=$ deirid; $\mathrm{GE}=$ glandular esophagus; $\mathrm{LA}=$ lateral alae; $\mathrm{ME}=$ muscular esophagus; $\mathrm{NR}=$ nerve ring; $\mathrm{PT}=$ pointed tip. 


\section{Discussion}

Chabaud analyzing the cephalic structures of habronematid nematodes, relocated some species described as Habronema Diesing, 1861, creating the Procyrnea subgenus within the genus Cyrnea Deshayes, 1858. Finally, Chabaud's work establishes the Procyrnea as genus (Zhang et al., 2004). Procyrnea nematodes are bird parasites, mainly in birds of prey of the Falconiformes and Strigiformes orders around the world (Eduardo \& Villa, 2011; Bagnato et al., 2018). They use as an intermediate host an orthopteran insect in whose hemocele they develop from larvae to infective stage L3, remaining encapsulated or free inside (Anderson, 2000). Of ten species reported in Brazil, only two were observed in accipitrids: P. mansioni (Seurat, 1914) in Rupornis magnirostris (Gmelin); and P. leptoptera (Rudolphi, 1819) in R. magnisrostris, Geranospiza caerulescens caerulescens (Vieillot), Harpagus diodon (Temminck), Heterospizias meridionalis meridionalis (Latham), R. magnirostris magnisrostris (Gmelin) and R. magnirostris nattereri (Sclater \& Salvin) (Pinto et al., 1994; Vicente et al., 1995). In a recent publication, Procyrnea sp. has been reported in Geranoaetus polyosoma (Quoy \& Gaimard) (Aves: Accipitridae) in Chile (Grandón-Ojeda et al., 2019).

Species of the genus parasitize the upper digestive system of birds, especially the ventricle and proventriculus (Arrona-Rivera et al., 2016). Clinical examination of the bird showed dehydration and low weight, which may be related to Procyrnea parasitism, considering its physiological recovery after the establishment of the fluid therapy and deworming protocol. Failure to observe eggs in the parasitological examination of feces does not rule out this possibility since false negatives may occur in non-specific tests, such as this one.

Based on research in the specialized scientific literature, this is the first report of the occurrence of Procyrnea $\mathrm{sp}$. in B. schistaceus. No other reports of helminth parasitism were found in this bird of prey species, making this the first report of endoparasite in this bird.

\section{Acknowledgements}

The authors are grateful to the following: the Laboratório de Histologia e Embriologia Animal, Instituto da Saúde e Produção Animal, Universidade Federal Rural da Amazônia - UFRA, campus Belém, state of Pará, Brazil for the use laboratorial equipaments. This study is part of the Ph.D. thesis of Tiago Paixão Mangas, developed for the Programa em Saúde e Produção Animal da Amazônia, Universidade Federal Rural da Amazônia.

This study was financed in part by the Coordenação de Aperfeiçoamento de Pessoal de Nível Superior - Brasil (CAPES - Ministério da Educação do Brasil - Finance Code 001) and Raul Henrique da Silva Pinheiro was supported by a research fellowship from the "Universidade Federal do Oeste do Pará - CAPES - Ministério da Educação do Brasil - Finance Code 001"

\section{References}

Anderson RC. Nematode parasites of vertebrates: their development and transmission. 2nd ed. Wallingford: CABI Publishing; 2000. http://dx.doi.org/10.1079/9780851994215.0000.

Andery DA, Ferreira FC Jr, Araújo AV, Vilela DAR, Marques MVR, Marin SY, et al. Health Assessment of Raptors in Triage in Belo Horizonte, Mg, Brazil. Braz J Poult Sci 2013; 15(3): 247-256. http://dx.doi.org/10.1590/S1516-635X2013000300012.

Arrona-Rivera AE, Sánchez-Godoy FD, Hernández-Velasco X. Proventricular parasitosis by Procyrnea sp. (Spiruroidea: Habronematidae) in a roadside hawk (Rupornis magnirostris) from the state of Veracruz, Mexico: a case report. Acta Zool Mex 2016; 32(3): 225-229. http://dx.doi.org/10.21829/azm.2016.323958.

Bagnato E, Frixione M, Digiani MC, Cremonte F. A new species of Procyrnea (Nematoda: Habronematidae) parasitic in Rhea pennata (Aves: Rheidae) from Patagonia, Argentina, with a key to species of the genus. J Helmintho/ 2018; 92(4): 504-513. http:// dx.doi.org/10.1017/S0022149X17000657. PMid:28758604.

BirdLife International. The IUCN Red List of Threatened Species [online]. 2016 [cited 2019 Oct 23]. Available from: https://www. iucnredlist.org/species/22695745/93526639

Cram EB. Bird parasites of the nematode suborders Strongylata, Ascaridata and Spirurata. Bull United S Nat Mus 1927; 140(140): 1-465. http://dx.doi.org/10.5479/si.03629236.140.1.

Ederli NB, Oliveira FCR. Redescription of Procyrnea uncinipenis (Molin, 1860) (Nematoda: Habronematidae) based on material from Rhea americana (L.) (Aves: Rheidae). Syst Parasito/ 2019; 96(8): 735-745. http://dx.doi.org/10.1007/s11230-019-09880-w. PMid:31529331.

Eduardo SL, Villa FD. A new species of Procyrnea Chabaud 1975 (Nematoda: Habronematidae) and redescription of two chewing lice (Mallophaga) from the Palawan Hill Myna, Gracula religiosa palawanensis (Passeriformes: Sturnidae), Philippines. Philipp J Vet Med 2011; 48(2): 77-85. 
Freitas JFT, Lent H. "Spiruroidea" parasitos de "Rheiformes" (Nematoda). Mem Inst Oswaldo Cruz 1947; 45(4): 743-760. http:// dx.doi.org/10.1590/S0074-02761947000400002.

Grandón-Ojeda A, Cortés P, Moreno L, Kinsella JM, Cicchino A, Barrientos C, et al. Gastrointestinal and external parasites of the variable hawk Geranoaetus polyosoma (Accipitriformes: Accipitridae) in Chile. Rev Bras Parasitol Vet 2019; 28(3): 376-382. http:// dx.doi.org/10.1590/s1984-29612019045. PMid:31390433.

Niemuth JN, Allgood JV, Flowers JR, De Voe RS, Troan BV. Ventricular habronemiasis in aviary passerines. Case Rep Vet Med 2013; 2013: 719465. http://dx.doi.org/10.1155/2013/719465.

Oyarzún-Ruiz P, Muñoz-Alvarado P, Raffo E. Helminths of Milvago chimango temucoensis (Aves: Falconiformes) from Los Ríos Region, Chile: new records for neotropical raptors. Helminthologia 2016; 53(4): 336-353. http://dx.doi.org/10.1515/helmin-2016-0037.

Piacentini VQ, Aleixo A, Agne CE, Maurício GN, Pacheco JF, Bravo GA, et al. Lista comentada das aves do Brasil pelo Comitê Brasileiro de Registros Ornitológicos. Rev Bras Ornitol 2015; 23(2): 91-298.

Pinto RM, Vicente JJ, Noronha D. Nematode parasites of brazilian accipitrid and falconid birds (Falconiformes). Mem Inst Oswaldo Cruz 1994; 89(3): 359-362. http://dx.doi.org/10.1590/S0074-02761994000300010.

Pinto RM, Vicente JJ, Noronha D. Nematode Parasites of Brazilian Piciformes Birds: a General Survey with Description of Procyrnea anterovulvata n. sp. (Habronematoidea, Habronematidae). Mem Inst Oswaldo Cruz 1996; 91(4): 479-487. http://dx.doi.org/10.1590/ S0074-02761996000400015.

Robinson SK. Habitat selection and foraging ecology of raptors in amazonian Peru. Biotropica 1994; 26(4): 443-458. http://dx.doi. org/10.2307/2389239.

San Martín J, Brevis C, Rubilar L, Krone O, González-Acuña D. Parasitismo gastrointestinal en tiuque común Milvago chimango chimango (VIEILLOT, 1816) (Falconidae, Aves) en Ñuble, Chile. Parasitol Latinoam 2006; 61(1-2): 63-68. http://dx.doi.org/10.4067/ S0717-77122006000100009.

Santos PMS, Silva SGN, Fonseca CF, Oliveira JB. Parasitos de aves e mamíferos silvestres em cativeiro no estado de Pernambuco. Pesq Vet Bras 2015; 35(9): 788-794. http://dx.doi.org/10.1590/S0100-736X2015000900004.

Vicente JJ, Rodrigues HO, Gomes DC, Pinto RM. Nematóides do Brasil. Parte IV: nematóides de aves. Rev Bras Zool 1995; 12(Suppl. 1): 1-273. http://dx.doi.org/10.1590/S0101-81751995000500001.

Zhang L, Brooks DR, Causey D. Procyrnea Chabaud, 1958 (Nematoda: Habronematoidea: Habronematidae) in birds from the Area de Conservacion Guanacaste, Costa Rica, including descriptions of 3 new species. J Parasito/ 2004; 90(2): 364-372. http:// dx.doi.org/10.1645/GE-3261. PMid:15165061. 